\title{
The Effect of Picture Story Book Based on Scientific Approach with Discovery Method on Collaboration Attitude of Elementary Student
}

\author{
$1^{\text {st }}$ Fitria Fatmawati
}

Basic Education

Yogyakarta State University

Yogyakarta, Indonesia

fitria.fatmawati2016@student.uny.ac.id $2^{\text {nd }}$ Zuhdan Kun Prasetyo

Science Education

Yogyakarta State University

Yogyakarta, Indonesia

zuhdan@uny.ac.id

\begin{abstract}
The collaboration attitude is essential to be accustomed to the students so that the student can work well with others in the future. The collaboration attitude is also required to meet the demand of learning and innovation skills in the Industry 4.0,which emphasizes that students should have good collaborative skills. Unfortunately, the empirical foundation states that the collaboration attitude of the elementary school students has not been developed properly.Therefore, the objective of this study was to improve the collaboration school attitude of the elementary school students. This study aimed to investigate the effect of using the picture storybook based on a scientific approach with discovery method on the collaboration attitude in learning and the different influence of the storybook compared with two other scientific books (AAB and 2013 Curriculum book) on the collaboration attitude. The subjects of the study were 81 third-grade elementary school students in Gunung Kidul District, Yogyakarta. Data was collected using observations and questionnaires. Data were analyzed using ANOVA. The results of this study show that the picture storybook based on a scientific approach with discovery method gave a higher positive influence compared to AAB and 2013 Curriculum book. In other words, the use of the picture storybook based on a scientific approach with discovery method is effective as a learning resource book to improve the collaboration attitude of elementary school students.
\end{abstract}

Keywords - picture story book, collaboration attitude, elementary students.

\section{INTRODUCTION}

The changing transition of industrial development 4.0 influences many aspects of life, including education. The Indonesian Government has established the Law No. 2- of 2003 on National Education System, particularly on Article 3 which discusses the functions and objectives of national education. The core competencies emphasized in the $21^{\text {st }}$-century are learning and innovation skills, digital literacy, and life and career skills [1]. Learning and innovation skills consist of critical thinking skills, creativity, communication, and collaboration [2]. Logical consequences that occur when the competence is achieved are the increasing wealth and security of the nation in facing $21^{\text {st }}$ century challenges in various fields and competing with other countries. Therefore, improving the quality of education and teaching in Indonesia, especially in elementary school is essential to produce human resources, who are superior and quality in every era. One of the applications of the scientific approach in 2013 Curriculum is making the student to solve a problem in groups. This can be used as a solution to overcome the low level of collaboration attitude. In fact, although the scientific approach has been implemented by third-grade elementary school teachers in Wonosari, Yogyakarta.This did not bring a positive effect on elementary school students' collaboration attitude. The tendency of students to group with their friends and refusing to group with other students show the student's selfishness and the low level of collaboration attitude. Hence, it is essential to familiarizethe collaboration attitude withthe students as early as possible. Improving the collaborative skills of students is significantly influenced by the ability to communicate well [3]. By making the elementary students learning groups regularly,they will learn to develop their collaboration attitude and train students to the other group members in completing [4]. Students who have a good collaboration attitude can solve problems in group work easily [5], [6], [7].

In another study, three elements that affect children's attitudes are books, magazines, and learning materials in the family environment [8]. The book serves as a visual aid to illustrate the concepts described in the text that can help students to understand scientific concepts [9]. Books are often used by teachers or parents as a source of knowledge and tools in the learning process of children. In the 2013 Curriculum, the book used during the study is 
the thematic book of the 2013 Curriculum in the form of teacher books and student books. In addition to the 2013 thematic curriculum, teachers can also use other supplementarybooks in the learning process. The supplementarybook is a book that contains learning materials that match the learning theme in the 2013 Curriculum. Moreover, the supplementary book also must meet the requirements as stipulated in Ministry of Education and Culture Regulation No. 8 of 2016 on Books Used by Education Units. The regulation explains that the book used by an education unit is composed of textbooks and non-text books that are attractive, easily understood, have a high degree of legibility, and they fulfill the values relevance and prevailing in the community. One of the supplementary books that teachers can use is a science-based illustrated storybook with discovery method written by Anisa Yulistia.

A picture storybook based on a scientific approach with discovery method is a book adjusted to the intelligence level of elementary school children in terms of pictures, stories, and other contents. This book contains stories with lesson materials, which encourages students to perform activities in a scientific approach with discovery methods to improve the collaboration attitude of third-grade elementary school students. The picture storybookis expected to influence the collaboration attitude of third-grade elementary school students. In addition to using the storybook, this study also used the authentic assessment book (AAB) and 2013 Curriculum book to find out which book had the most significant influence on student collaboration attitude. The 2013 Curriculum book and AAB are scientific-based approach books with an authentic and activity-based assessment. The learning theme used wasthe seventh theme, namely 'Energy and Its Changes'. This theme was selected because many learning activities in this theme are in the form of group experiments. Therefore, it was used to measure the effect of the book on the student collaboration attitude.

The research problems were (1) whether the picture storybook based on a scientific approach with discovery method affects the student collaboration attitude, and (2) how the influence of the storybook differs from the AAB and 2013 Curriculum book. Therefore, through learning through picture book based on a scientific approach with discovery method, students are expected to develop collaboration attitude.

\section{LITERATURE REVIEW}

\section{A. Picture Story Book based on Scientific Approach with Discovery Method}

The picture storybook based on a scientific approach with discovery methodused in this study is written by [10]. This book has an integrative thematic design on several subjects. This book is adjusted to the intelligence level of elementary school children in terms of pictures, stories, and other contents.This book contains stories with lesson materials, which encourages students to perform activities in a scientific approach with discovery methods to improve the collaboration attitude of third-grade elementary school students

A picture storybook helps children's learning process and builds their thinking skills, perceptions and interpretations of the environment, and fostering their sensitivity to the environment [11]. A storybook that contains a continuous story about the daily life is very useful in a discussion so that students can comment on their daily lifewhile also preparing students for their future [12], [13]. The choice of the story can be adapted to the material to be discussed in the lesson, for example, electrical or forces in the science subject. The story content should contain questions that can stimulate students to find out the answer [14]. Several benefits that students gain through learning using picture storybooksare: (1) learning using picture storybooks helps low-grade students to understand and implement the learned material [15]; (2) learning using picture storybooks helps students to learn about new vocabularies receptively and expressively [16], [17]; (3) graphic design elements and written text broaden the perspective of students in understanding important texts or instructions [18] and (4) a picture storybookhelps students to develop scientific information and present evidence based on scientific information, and it helps teachers to facilitate cognitive and affective involvement of the student with literacy and science [19].

\section{B. Other Supplementary Books}

Other supplementary books used in this study were the 2013 Curriculum book and the authentic assessment book (AAB). The 2013 Curriculum book is a textbook compiled by the government for elementary school teaching. The 2013 Curriculum book consists of teacher books and student books. It contains a variety of learning materials and practice questions that are packed in integrative thematic from several subjects into one learning theme. One learning theme consists of $3-4$ subthemes of learning, and each subtheme has sixlessons.

The authentic assessment book (AAB) is a book developed to help teachers implement the 2013 Curriculum. The book is presented in accordance with the Government's 2013 thematic textbooks by accommodating concept exploration, activities, practice, and assignment. The main purpose of AAB presentation is to help students to carry out the scientific learning process and help teachers to do an authentic assessment [20]. The AAB is similar to the 2013 Curriculum book that consists of one theme which is then divided into $3-4$ subthemeswith each subtheme has six lessons. Characteristics of the AABare: based on scientific learning, supplemented with authentic assessment sheets and written test. 


\section{Collaborative Attitude}

A collaboration attitude is a combination of individual attitudes formed based on a mutual commitment that is manifested in the form of a group attitude and behavior in accordance with procedures to obtain benefits and achieve common goals [21]. Cooperative-oriented learning activities can increase students' understanding of the material, as students have the opportunity to exchange knowledge in the form of opinions, ideas, or thoughts.Engaging with others can open opportunities for evaluating and improving students' understanding [22]-[24]. Some educators have realized that learning that develops students who are smart, critical, and creative and able to work together in solving daily life problems is essential [25]. This is because, during the learning process, the learners put more emphasis on learning about a thing rather than learning how to be. The collaboration attitude based on active, studentcentered learning is reflected in new experiences during group work by giving feedback to group members [26]. It provides an understanding that student-centered learning with teachers as the facilitators develops a mental framework built on the basis of prior knowledge, enabling group learning and interaction. Some aspects that reflect the collaboration attitude are (1) group ability; (2) intimacy and sincerity; and (3) the ability to do group work [27], [28]. Teachers can develop student collaboration by encouraging individual independence and accountability, grouping heterogeneously, fostering a sense of shared leadership, asking students to share responsibilities with each other in task work, teaching social skills directly, observing and intervening, and helping the group to process its effectiveness [29]. This study used group activity-based books to analyze their effect on the collaborationattitude.

Hypotheses in this research were: 1) The picture storybook based on a scientific approach with discovery method have a positive and significant effect on the collaboration attitude of third-grade elementary school students, and 2) There is a different effect of the storybook, 2013 Curriculum, and $\mathrm{AAB}$ on the collaboration attitude of third-grade elementary school students.

\section{METHOD}

This was a quantitative study with a quasiexperimental approach. The study used a pre-testposttest nonequivalent control group design. The study design according to [30] is illustrated in Figure 1.

\begin{tabular}{|c|c|c|}
\hline Grup A & $\mathrm{RO}_{1}$ & 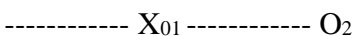 \\
\hline Grup B & $\mathrm{RO}_{3}$ & - $\mathrm{X}_{02}$-- \\
\hline Grup C & $\mathrm{RO}_{5}$ & --_--- $\mathrm{X}_{03}$ \\
\hline
\end{tabular}

The study population was all third-grade elementary school students in Wonosari in 2017/2018 academic year. The samplingused the simple random sampling technique, by choosing the required participants toobtain class III A, B, and C of Wonosari I elementary school as the study sample. The respective experiment class 1,2 , and 3 were class III A, B, and C with 27 students in each class. Thus, the total number of students was 81 students. The treatment of study subjects is presented in Table 1 .

Table 1. Research Sample

\begin{tabular}{|c|c|c|c|c|}
\hline No & $\begin{array}{l}\text { Kind of } \\
\text { Class }\end{array}$ & $\begin{array}{c}\text { Amount of } \\
\text { student }\end{array}$ & Treatment & \\
\hline 1 & A & 27 & Experiment 1 & $\begin{array}{l}\text { (with Picture } \\
\text { Story Book) }\end{array}$ \\
\hline 2 & B & 27 & Experiment 2 & $\begin{array}{c}\text { (with } \\
\text { curricullum } \\
2013 \text { book ) }\end{array}$ \\
\hline 3 & $\mathrm{C}$ & 27 & Experiment 3 & $\begin{array}{c}\text { (with AAB } \\
\text { book) }\end{array}$ \\
\hline \multicolumn{2}{|c|}{ Total } & & 81 & \\
\hline
\end{tabular}

The data was collected via questionnaires (nontest). The questionnaireswere used to know the respondents' opinion on the collaboration attitude during learning. Questionnaires were given twice,once at the beginning of the study along with the pre-test and the other one at the end of the study along with the post-test. The collaboration attitude was measured using questionnaires given before (pretest) and after (post-test) treatment. The preparation of the collaboration attitude tablewas based on the opinions of [29] and [28], which state that the collaboration attitude includes group ability, and intimacy and ability to do group tasks. The collaboration attitude table is presented in Table 2 .

Table 2. Collaboration Attitude

\begin{tabular}{|c|c|c|}
\hline No & Aspect & Indicators \\
\hline 1. & Group ability & Work effectively \\
\hline 2. & Intimacy & $\begin{array}{l}\text { a. Compromised with other in } \\
\text { group } \\
\text { b. Giving attention to group }\end{array}$ \\
\hline 3. & $\begin{array}{l}\text { The ability to do } \\
\text { group work }\end{array}$ & $\begin{array}{ll}\text { a. } & \begin{array}{l}\text { Responsible for all group } \\
\text { task }\end{array} \\
\text { b. } & \begin{array}{l}\text { Respect for opinions from } \\
\text { other }\end{array}\end{array}$ \\
\hline
\end{tabular}

The first research problem of whether the picture storybook based on a scientific approach with discovery methodaffects the student collaboration attitude was answered with the paired-sample t-test. Meanwhile, the second research problem of how the influence of the storybook differs from the AAB and 2013 Curriculum bookwas answered with ANOVA.

\section{A. Result}

The prerequisite assumption test was performed prior to hypothesis testing of collaboration attitude for experimental groups1, 2, and 3. Assumption test was done through normality test using the Kolmogorov-Smirnov test, and homogeneity test using Lavene test. The result shows that the data was homogeny and distributed normally because both of the significant valueswere greater than 0.05 . 
The study used the paired t-test to analyze the mean of collaboration attitude before (pre-test) and after (post-test) treatment. The results of the paired ttest are presented in Table 3.

Table 3. Sample Paired Test

\begin{tabular}{|c|c|c|c|c|c|}
\hline Data & Condition & Mean & Sig. & $\mathrm{t}$ & \\
\hline \multirow{2}{*}{$\begin{array}{c}\text { Class A } \\
\text { (Picture } \\
\text { story } \\
\text { book) }\end{array}$} & Pretest & \multirow[b]{2}{*}{6.87593} & \multirow[b]{2}{*}{0,000} & & \multirow{2}{*}{$\begin{array}{c}\text { Signifikan } \\
(\mathrm{p}<0,05)\end{array}$} \\
\hline & Postest & & & $7.215^{-}$ & \\
\hline \multirow{2}{*}{$\begin{array}{l}\text { Class B } \\
\text { (K13) }\end{array}$} & Pretest & \multirow{2}{*}{6.80198} & \multirow{2}{*}{0,000} & \multirow{2}{*}{6.676} & \multirow{2}{*}{$\begin{array}{c}\text { Signifikan } \\
(\mathrm{p}<0,05)\end{array}$} \\
\hline & Postest & & & & \\
\hline \multirow{2}{*}{$\begin{array}{l}\text { Class C } \\
(\mathrm{AAB})\end{array}$} & Pretest & \multirow{2}{*}{ 6,66617 } & \multirow{2}{*}{0,000} & \multirow{2}{*}{$4,166^{-}$} & \multirow{2}{*}{$\begin{array}{c}\text { Signifikan } \\
(\mathrm{p}<0,05)\end{array}$} \\
\hline & Postest & & & & \\
\hline
\end{tabular}

The results show that the $\mathrm{H}_{\mathrm{a} 1}, \mathrm{H}_{\mathrm{a} 2}$ and $\mathrm{H}_{\mathrm{a} 3}$ hypotheses were accepted because the significance values 0.000 were smaller than $0.05(\mathrm{p}=0.000<0.05)$. Thus, the storybook, the 2013 Curriculum book, and $\mathrm{AAB}$ had a positive and significant effect on collaboration attitude of third-gradeelementary school students. It also means that the mean between pre-test and post-test in the three classes had different outcomes in which scientifically based book-based illustrated storybooks using discovery methods show the storybook had a higher mean increase from pretest to post-test than the 2013 Curriculum book and $\mathrm{AAB}$. The next test was the univariate test or ANOVA to answer how the influence of the picture storybook differs from the AAB and 2013 Curriculum book The ANOVA test results are displayed in Table 4.

\section{Table 4. ANOVA}

\begin{tabular}{|c|c|r|c|c|c|}
\hline & $\begin{array}{c}\text { Sum of } \\
\text { Squares }\end{array}$ & df & $\begin{array}{c}\text { Mean } \\
\text { Square }\end{array}$ & F & Sig. \\
\hline $\begin{array}{c}\text { Between } \\
\text { Groups }\end{array}$ & 583.531 & 2 & 291.765 & 11.405 & .000 \\
\hline $\begin{array}{c}\text { Within } \\
\text { Groups }\end{array}$ & 1995.473 & 78 & 25.583 & & \\
\hline Total & 2579.003 & 80 & & & \\
\hline
\end{tabular}

The ANOVA test results show that the significance value (0.000) was smaller than 0.05 ; thus, the $\mathrm{H}_{0}$ was rejected. Therefore, there was a meaningful difference effect from the use of the storybook, AAB and 2013 Curriculum book on collaboration attitude of third-grade elementary school students. The next step was the tests of between-subjects effects.

Table 5. Tests of Between-Subjects Effects

\begin{tabular}{|l|l|l|l|l|l|c|}
\hline Source & $\begin{array}{l}\text { Type III } \\
\text { Sum of } \\
\text { Squares }\end{array}$ & df & $\begin{array}{l}\text { Mean } \\
\text { Square }\end{array}$ & F & Sig. & $\begin{array}{c}\text { Partial } \\
\text { Eta } \\
\text { Squared }\end{array}$ \\
\hline Kelas & 583.531 & 2 & 291.765 & 11.405 & .000 & .226 \\
\hline \multicolumn{7}{|l|}{ a. R Squared $=.226$ (Adjusted R Squared $=.206$ ) } \\
\hline
\end{tabular}

Based on the result of the univariate test analysis using tests of between-subjects effects at post-test value, the $F_{\text {calc }}$ of collective collaboration attitude variable was 1.313 with the significance of 0.000 , which wassmaller than 0.05 ( $\mathrm{p}<0.05)$. These values indicate that the three books had the same effect on the collaboration attitude of third-gradeelementary school students. The effect of all three books together on the student collaboration attitude is shown in the partial eta squared column of 0.226 . To analyze the influence of each book on student collaboration attitude, Tukey's test is presented in Table 6.

Table 6. Tukey's test

\begin{tabular}{|l|l|l|l|l|}
\hline $\begin{array}{l}\text { (I) } \\
\text { Collaboration }\end{array}$ & (J)Collaboration & $\begin{array}{l}\text { Mean } \\
\text { Difference } \\
\text { (I-J) }\end{array}$ & Std. Eror & Sig. \\
\hline \multirow{2}{*}{ Class A } & Class B & $6.2098^{*}$ & 1.37660 & 0.00 \\
\cline { 2 - 5 } & Class C & $4.9751^{*}$ & 1.37660 & 0.02 \\
\hline \multirow{2}{*}{ Class B } & Class A & $-6.2098^{*}$ & 1.37660 & 0.00 \\
\cline { 2 - 5 } & Class C & -1.2347 & 1.37660 & 0.64 \\
\hline Class C & Class A & $-4.9751^{*}$ & 1.37660 & 0.02 \\
\cline { 2 - 5 } & Class B & 1.2347 & 1.37660 & 0.64 \\
\hline Based on observed means. \\
\hline \multicolumn{4}{|l|}{ The error term is Mean Square (Error) $=25.583$} \\
\hline \multirow{2}{*}{ *. The mean difference is significant at the 0.05 level. } \\
\hline
\end{tabular}

The storybook's significance value of the collaboration attitude variable on class $\mathrm{B}$ and $\mathrm{C}$ were 0.000 and 0.002 , respectively. This means that the storybook had a significant effect on collaboration attitude compared to the 2013 Curriculum book and AAB. The collaboration attitude value of the storybook was 6.2098 times greater than the 2013 curriculum book and 4.9751 times greater than the AAB. As can be seen in the Tukey test results in Table 6, the storybook had the greatest influence on collaboration attitudecompared to the 2013 Curriculum book and AAB.

\section{B. Discussion}

The paired t-test resultsshow that on the variable of collaboration attitude: $\mathrm{H}_{\mathrm{a} 1}, \mathrm{H}_{\mathrm{a} 2}$, and $\mathrm{H}_{\mathrm{a} 3}$ were accepted with significance value $0.000(\mathrm{sig}=<0.05)$. This means that the mean between pre-test and posttest in class $\mathrm{A}, \mathrm{B}$, and $\mathrm{C}$ was different on the collaboration attitude variable. Based on the ANOVA analysis, the combination of the storybook, the 2013 Curriculum book, and AAB had a positive effect on the collaboration attitude, but with different degree of influence. Based on Tukey's test result, the mean difference of the storybook was 6.2098 times larger than the 2013 Curriculum book and 4.9751 times larger than the $\mathrm{AAB}$.

The collaboration attitude is the cooperation behavior of someone for others to achieve certain goals more quickly. Based on the analysis results, the picture storybook based on a scientific approach with discovery method had a positive and significant effect on the collaboration attitude of third-grade elementary school students. This could be caused by the fact that the storybook presents activity-based learning to help teachers and students to complement and enrich material from various sources and learning activities 
The cooperative-oriented learning activities can increase students' understanding of the material, as students have the opportunity to exchange knowledge in the form of opinions, ideas, or thoughts.Engaging with others also can open opportunities for evaluating and improving understanding. This is similar to Lakoy's (2015: 983) view that collaboration with other students can be demonstrated by the ability to work effectively, the inclination of compromise to achieve common goals, creating a shared sense of responsibility for collaborative work, and having respect for the opinions of other group members.

Collaboration can be defined as a skill of team work. Teamwork or collaborative was identified as one of eleven essential learning outcomes in the seminal AACU report College Learning for the New Global Century [31]. However, an important aspect of collaborative work is its group formation [32]. Over the years, several methods of collaborative group formation have been proposed by the researchers. These have been implemented from the learner as well as instructor point of view. The simplest way of doing this is to let the learners choose their own groups [33]. It has been found that in this case, learners tend to chose groups based on friendship rather than background learning. These groups generally contain learners with similar collaborative skills and knowledge levels. The learning in this study was designed in groups. Each class was divided into five small groups. Experiments were done to develop student collaboration attitude. The experiments had has a positive impact on students' understanding of others. Therefore, the collaboration attitude can be measured through the observation of student interaction. Some other aspects that reflect the collaboration attitude are (1) group ability; (2) intimacy and sincerity; and (3) the ability to do group work [28]. The analysis results show that the mean was increased from pre-test to post-test, with the highest student collaboration attitude was achieved by class A, followed by class B, and lastly, class C. In this study, assessmentof the student's collaboration attitude was done by combining the results of self-assessment questionnaire, assessment between friends, and researchers' observations. The results then divided by three to obtain themean of the collaboration attitude. The overall mean score of each indicator shows the increase from pre-test to post-test.

Learning using scientific approach can create a symmetrical relationship between teachers with students and students with students. The scientific approach encourages students to be more independent but not selfish and can face and think critically when solving problems [3]. Therefore, the scientific approach could help students to develop their collaboration attitude. However, it takes more time and effort from the teacher to condition the students to get the students used to collaboration. The teacher's role in facilitating the student's collaboration attitude is by focusing on the student's practices or experiments. The practices can be used to measure the number of conscious interactions that teachers made to small groups of students, as well as the interaction between students and groups of students. In conclusion, the book that gives apositive effect on the collaboration attitude is the picture storybook based on a scientific approach with discovery method.

\section{CONCLUSION}

1 There was a positive and significant influence of the use of the picture storybook based on a scientific approach with discovery methodon the collaboration attitude of third-grade elementary schoolstudents. This is shown by $t_{\text {calc }}$ value of the storybook in Class III A, which reached 7.215 for $\mathrm{df}=26$ at $5 \%$ significance level of 6.87593. From the experimental class, the pvalue is less than $0.05(\mathrm{p}=0.000<0.05)$.

2 The combination use of the storybook, the 2013 Curriculum book, and the authentic assessment book showed the difference effect on collaboration attitude of third-grade elementary school students. This can be seen from ANOVA test results that showeda p-value smaller than $0.05(\mathrm{p}=0.000<0.05)$. In addition, based on the Tests of Between-Subjects Effects on the posttest value, the three books had the same interaction effect on collaboration attitude of third-grade elementary school students. The effect of all three books together was 0.226. However, the picture storybook based on a scientific approach with discovery methodhad the highest influence compared to the 2013 Curriculum book and the authentic assessment book.

\section{ACKNOWLEDGMENT}

This research was supported/partially supported by LPDP (Lembaga Pengelola Dana Pendidikan) and Postgraduate of Yogyakarta State University esspecially majoring in basic eduction. The research presents his sincere appreciation goes to my advisor Mr. Zuhdan Kun Prasetyo this research would not have been possible without the help, support and patience for his supervision, advice, and guidance from the very early stage of this research as well as giving me extraordinary experiences throughout the past few years.

I gratefully thank to the principal of elementary school in Gunung Kidul for allowing me to conduct the research there. Also to the Third grade teachers in that school Ms. Trini, Ms. Fitria, and Ms. Yanik for allowing me to conduct my research in her class. I could never have finished this without your great guidance. 


\section{REFERENCES}

[1] A. S. R. Alghafri and H. N. Bin Ismail, "The Effects of Integrating Creative and Critical Thinking on Schools Students' Thinking," Int. J. Soc. Sci. Humanit., vol. 4, no. 6, pp. 518-525, 2014

[2] B. Trilling and C. Fadel, "21st Century Skills Learning for Life in our Times," Am. Educ., p. 206, 2010.

[3] A. P. \& D. Utami, "Kemampuan Komunikasi, Kolaborasi, Metakognisi, Dan Hasil Belajar Mata Pelajaran Teknologi Mekanik Siswa Kelas X Pada Penerapan Pendekatan Saintifik Smkn 1 Kediri," JPTM, vol. 5, pp. 17-26, 2017.

[4] R. M. Gillies and A. F. Ashman, "Teaching collaborative skills to primary school children in classroom-based work groups," Learn. Instr., vol. 6, no. 3, pp. 187-200, 1996.

[5] G. Gunantara, M. Suarjana, and P. N. Riastini, "Penerapan Model Pembelajaran Problem Based Learning untuk Meningkatkan Kemampuan Pemecahan," J. Mimb. PGSD Univ. Pendidik. Ganesha, vol. 2, no. 1, pp. 1-10, 2014.

[6] A. Karim, "Penerapan Metode Penemuan Terbimbing Dalam Pembelajaran Matematika Untuk Meningkatkan Pemahaman Konsep Dan Kemampuan Berpikir Kritis Siswa Sekolah Dasar," J. Penelit. Pendidik., vol. Edisi Khus, no. 2, pp. 154-163, 2011.

[7] Sri Astutik, "Meningkatkan Hasil Belajar Siswa Dengan Model Siklus Belajar (Learning Cycle 5e) Berbasis Eksperimen Pada Pembelajaran Sains Di Sdn Patrang I Jember," J. Ilmu Pendidik. Sekol. Dasar, vol. 1, no. 2, pp. 144-153, 2012.

[8] S. B. Djamarah, Psikologi Belajar. Jakarta: Rineka Cipta.

[9] A. J. Tobin, Asking About Life. Canada: Thomson Brooks/Cole.

[10] A. Yulistia, "Pengembangan buku cerita bergambar berbasis scientific approach dengan metode discovery learning untuk meningkatkan kemampuan berpikir kreatif dan sikap kerja sama siswa kelas III SD," Universitas Negeri Yogyakarta, 2017.

[11] M. Gönen, M. Durmuşoğlu, and S. Severcan, "Examining the views of preschool education teachers on the content, illustrations and physical characteristics of the picture story books used in education," Procedia - Soc. Behav. Sci., vol. 1, no. 1, pp. 753-759, 2009.

[12] N. Tucker, The child and the book: A psychological and literary exploration. Cambrige: Press Syndicate of The University of Cambrige, 1981.

[13] J. Huck, C. S., Hepler, S., \& Hickman, Children's Literature in The Elementary School. New York: Holt, Rinehart and
Winston, 1987.

[14] J. Ward, H., Roden, J., Hewlett, C., \& Foreman, Teaching Science in Primary School: Practical Guide. London: SAGE Publications Ltd, 2008.

[15] D. Kelemen, N. A. Emmons, R. Seston Schillaci, and P. A. Ganea, "Young Children Can Be Taught Basic Natural Selection Using a Picture-Storybook Intervention," Psychol. Sci., vol. 25, no. 4, pp. 893-902, 2014.

[16] M. J. A. J. Verhallen and A. G. Bus, "LowIncome Immigrant Pupils Learning Vocabulary Through Digital Picture Storybooks," J. Educ. Psychol., vol. 102, no. 1, pp. 54-61, 2010.

[17] M. F. Collins, "ELL preschoolers' English vocabulary acquisition from storybook reading," Early Child. Res. Q., vol. 25, no. 1, pp. 84-97, 2010.

[18] F. Serafini, "Expanding Perspectives for Comprehending Visual Images in Multimodal Texts," Int. Electron. J. Elem. Educ., vol. 6, no. 2, pp. 257-274, 2014.

[19] P. Mantzicopoulos and H. Patrick, "Reading picture books and learning science: Engaging young children with informational text," Theory Pract., vol. 50, no. 4, pp. 269-276, 2011.

[20] W. Astuti, I. M. J., Adhalia, D., \& Kristianti, BUPENA buku penilaian autentik tema energi dan perubahannya untuk sekolah dasar kelas 3 semester 2. 2015.

[21] A. C. Lakoy, "Pengaruh Komunikasi, Kerjasama Kelompok, dan Kreativitas terhadap Kinerja Karyawan pada Hotel Aryaduta Manado," J. EMBA, vol. 3, no. 3, pp. 981-991, 2015.

[22] P. G. Clark, "Examining the interface between interprofessional practice and education: Lessons learned from Norway for promoting teamwork," J. Interprof. Care, vol. 25, no. 1, pp. 26-32, 2011.

[23] P. Tarricone and J. Luca, "Successful teamwork: A case study," Proc. 25th HERDSA Annu. Conf. Perth, West. Aust. 7-10 July 2002, no. July 2002, pp. 640-646, 2002.

[24] A. Suprijono, Cooperative Learning. Yogyakarta: PUSTAKA PELAJAR, 2013.

[25] D. Apriono, "Pembelajaran Kolaboratif: Suatu Landasan untuk Membangun Kebersamaan dan Keterampilan Kerjasama," Diklus, no. September, pp. 292-304, 2013.

[26] P. Hrynchak and H. Batty, "The educational theory basis of team-based learning," Med. Teach., vol. 34, no. 10, pp. 796-801, 2012.

[27] M. Hoegl and H. G. Gemuenden, "Teamwork Quality and the Success of Innovative Projects: A Theoretical Concept and Empirical Evidence," Organ. Sci., vol. 12, no. 4, pp. 435-449, 2001. 
[28] et. al Martin, Teaching Science for All Children. New York: Pearson.

[29] J. Abrustaco, Teaching Children Science: A Discovery Approach. New York: Allyn And Bacon., 1996.

[30] J. C. Campbell, D. T.; Stanley, "Chapter 5 Experimental and Quasi-Experimental Designs for Research," in Experimental and Quasi-Experimental Designs for Research, Ravenio Books, 1963, pp. 1-71.

[31] K. E. Dunn and S. W. Mulvenon, "A Critical Review of Research on Formative Assessments: The Limited Scientific Evidence of the Impact of Formative Assessments in Education," Pract.
Assessment, Res. Eval., vol. 14, no. 7, pp. 1$11,2009$.

[32] A. Acharya and D. Sinha, "A 'Mixed' Strategy for Collaborative Group Formation and Its Learning Outcomes," J. Educ. Technol. Syst., vol. 0, no. 0, p. 0047239517749246, 2018.

[33] J. Abrami, P. C., Chambers, B., Poulsen, C., De Simone, C., d'Apollonia, S., \& Howden, Classroom connections: Understanding and using cooperative learning. Toronto: ON: Harcourt Brace \& Company, 1995. 